\title{
Detection of NP, N3 and N7 antibodies to avian influenza virus by indirect ELISA using yeast-expressed antigens Chitra Upadhyay ${ }^{1}$, Arun Ammayappan ${ }^{1,2}$ and Vikram N Vakharia*1
} Address: ${ }^{1}$ Center of Marine Biotechnology, University of Maryland Biotechnology Institute, 701 East Pratt Street, Baltimore, Maryland $21202-$
3101, USA and ${ }^{2}$ Department of Veterinary Medicine, University of Maryland, College Park, Maryland 20742, USA

Email: Chitra Upadhyay - upadhyay@umbi.umd.edu; Arun Ammayappan - ammayapp@umbi.umd.edu; Vikram N Vakharia* - vakharia@umbi.umd.edu

* Corresponding author

Published: 7 October 2009

Virology Journal 2009, 6:158

doi: $10.1186 / 1743-422 X-6-158$

This article is available from: http://www.virologyj.com/content/6/I/I58

C 2009 Upadhyay et al; licensee BioMed Central Ltd.

This is an Open Access article distributed under the terms of the Creative Commons Attribution License (http://creativecommons.org/licenses/by/2.0), which permits unrestricted use, distribution, and reproduction in any medium, provided the original work is properly cited.
Received: 28 June 2009

Accepted: 7 October 2009

\begin{abstract}
Background: Avian influenza viruses, belonging to the family Orthomyxoviridae, possess distinct combinations of hemagglutinin $(\mathrm{H})$ and the neuraminidase $(\mathrm{N})$ surface glycoproteins. Typing of both $\mathrm{H}$ and $\mathrm{N}$ antigens is essential for the epidemiological and surveillance studies. Therefore, it is important to find a rapid, sensitive, and specific method for their assay, and ELISA can be useful for this purpose, by using recombinant proteins.

Results: The nucleoprotein (NP) and truncated neuraminidase subtype 3 and 7 of avian influenza virus (AIV) were expressed in Saccharomyces cerevisiae and used to develop an indirect enzymelinked immunosorbent assay for antibody detection. The developed assays were evaluated with a panel of 64 chicken serum samples. The performance of NP-ELISA was compared with the commercially available ProFlok ${ }^{\circledR}$ AIV ELISA kit. The results showed comparable agreement and sensitivity between the two tests, indicating that NP-ELISA assay can be used for screening the influenza type A antibody in AIV infected birds. The N3 and N7- ELISAs also reacted specifically to their type specific sera and did not exhibit any cross-reaction with heterologous neuraminidase subtype specific sera.

Conclusion: The study demonstrates the expression of the NP, N3, and N7 proteins of AIV in yeast (S. cerevisiae) and their application in developing an indirect ELISA for detecting NP, N3 and N7 antibodies from AIV-infected chicken sera. The described indirect ELISAs are rapid, sensitive, specific and can be used as promising tests during serological surveillance.
\end{abstract}

\section{Background}

Influenza viruses belong to the Orthomyxoviridae family. The influenza viruses are characterized into three types: $\mathrm{A}$, $\mathrm{B}$ and $\mathrm{C}$, based on the structural (nucleoprotein [NP]) and matrix [M] proteins ([1]. Type A viruses are further classified into subtypes based on the surface glycoproteins; hemagglutinin (HA or $\mathrm{H}$ ) and neuraminidase (NA or $\mathrm{N}$ ) [2]. Currently, sixteen HA subtypes (H1-H16) and nine
NA subtypes (N1-N9) have been recognized [3-7]. The virus has been recovered from domestic and wild avian species throughout the world and has high impact on international trade in poultry and poultry products $[2,8,9]$.

From late 2003 to July 2009, AI outbreaks in poultry has been reported in Asia, including China, Vietnam, Thai- 
land, India, Bangladesh and other countries ([10,11]. AIV has become an important potential risk factor for human health. Since May 2005, the numbers of both affected countries and confirmed cases of influenza A (H5N1) virus infection in humans have been increased [12].

Serological surveillance of antibodies against AIV is of great importance in preventing and controlling AI. Identification of both $\mathrm{H}$ and $\mathrm{N}$ subtypes is highly essential for the epidemiological and surveillance studies [13]. The widely used agar gel immunoprecipitation (AGP) test detects antibodies to both the NP and M proteins. However, the test has lower sensitivity as compared to the ELISA and HI tests [14] and it requires large quantities of both antigen and antibody to form the precipitation line. Hemagglutination inhibition (HI) and neuraminidase inhibition (NI) assays are the commonly used tests for detection of $\mathrm{H}$ or $\mathrm{N}$ subtypes and both these tests are laborious and time consuming. In addition, there are no standard reagents available for these tests, which lead to lab to lab variation in the interpretation of the result, thus demanding alternative tests which should be more accurate, reliable and replicable. HI test is also limited to detect hemagglutinin subtype and requires working with live virus, which is of major concern as it may allow dissemination of thevirus. The tests currently available for detection of AIV, such as the Flu Detect (Synbiotics) FLU OIA TEST (Biostar) and the Directigen FLU A kit (BD, Biosciences) $[15,16]$, are based on the detection of the viral nucleoprotein, which is conserved in all influenza A viruses and does not provide the information about the circulating neuraminidase subtypes. Thus, it is important to develop a serological assay which is safe, sensitive, specific, cost-effective, and easy to perform, especially for its application in developing and underdeveloped countries.

Recombinant proteins of AIV have been produced in expression systems using prokaryotic or eukaryotic host organisms [17-21]. The commonly preferred models for protein expression are the E. coli and insect-cell culture systems. Yeasts expression systems are attractive alternatives for the production of heterologous proteins. Their eukaryotic subcellular organization allows them to carry out the post-translational folding, processing and modifications required to produce bioactive mammalian proteins. In addition, yeast combines the simplicity and costeffectiveness of bacterial expression systems and is better than the more expensive and less convenient cell culture systems [22]. To date, there are no reports of using yeast expressed AIV recombinant proteins as antigens for ELISA. To the best of our knowledge, this is the first report of expressing NP, N3 and N7 proteins of AIV in S. cerevisiae and the development of an indirect ELISA test.

\section{Methods}

\section{Serum samples}

A panel of sera containing 64 chicken serum samples, of which 24 were AIV-positive and remaining 40 were AIVnegative, was used in this study. AIV positive sera were purchased from National Veterinary Service Laboratory, Iowa USA (Table 1). Positive sera for Newcastle disease (ND), infectious bursal disease (IBD) were obtained from Synbiotics Inc., CA USA and serum for infectious bronchitis (IB) was purchased from Charles River Laboratories, MA USA. Out of 40 serum samples, 37 were from chickens negative for AIV (Georgia Poultry Laboratory, GA USA, and Synbiotics, Inc., CA USA) and the rest were positive for Newcastle disease (ND), infectious bursal disease (IBD) and infectious bronchitis (IB) obtained from Synbiotics and Charles River Laboratories respectively.

\section{Cloning of AIV genes}

The NP gene [A/Ck/HK/CSW161/2003 (H9N2)] was amplified by reverse transcription-polymerase chain reaction (RT-PCR) using the upstream primer NPEcoF (5'CGAATTCATGGCGTCTCAAGGCACCAAACGA-3') and downstream primer NPHisR5'-CAAGCTTCAATGGTGATGGTGATGATGATTGTCATACTCCT-3'). Both the primers contained EcoRI site at their $5^{\prime}$ and $3^{\prime}$ end, respectively and a $6 \times$ Histidine tag was incorporated at the C-terminus of the NP gene. Similarly, the truncated N3 [A/mallard/ duck/ALB/279/1977 (H7N3) and N7 genes [A/pintail/ duck/ALB/303/1977 (H10N7)] were amplified using their respective primer pairs (N3TBamF:5'-GGGATCCATGACAGATGGCCCTGCTGCTAATAG-3'; N3TXhoR:5'CCTCGAGGCCCTTGGTTTTGACAATGAAAC-3' and N7TBamF:5'-GGGATCCATGACCGACGGATCGGCTAGTAG-3'; N7TXhoR:5'-CCTCGAGTTCACTGTTATCATTCCAATAGTC-3').

The amplified products were cloned into the PCR2.1 vector (Invitrogen, CA, USA) following manufacturer's instructions and called as pCR-NP, pCR-N3/N7 plasmids. The integrity of the plasmid was verified by sequencing the DNA using an automated DNA sequencer (Applied Biosystems, CA, USA). The pCR-NP plasmid was digested with EcoRI and the NP gene was cloned in the unique EcoRI site of $S$. cerevisiae expression vector pESC-URA (Stratagene, La Jolla, CA) downstream of the GAL10 promoter. The amplified truncated neuraminidase subtype 3 (N3T) and 7 (N7T) genes were subcloned between BamHI and SalI sites of pESC-URA vector downstream of the GAL1 promoter. The inserts ( $0.525 \mathrm{~kb}$ fragment) were ligated in-frame with the $\mathrm{c}-\mathrm{Myc}$ tag (present in the vector) at the $\mathrm{C}$ terminus of N3T and N7T proteins.

\section{Expression of NP, N3, and N7 proteins in yeast}

The pESC-derived expression plasmids carrying the NP, N3 and N7 protein-encoding sequences were transformed 
Table I: List of strain or source used for raising AIV serum employed in this study.

\begin{tabular}{|c|c|c|c|}
\hline Type & Strain or Source & Type & Strain or Source \\
\hline $\mathrm{NI}$ & A/EQUINE-I-SW/TENN/3/76 (H7NI) & $\mathrm{H} 4$ & A/Mynah/Mass/7I (H4N8) \\
\hline N2 & A/TY/Mass/65 (H6N2) & H5 & A/TY/Wisconsin/68 (H5N9) \\
\hline N3 & NWS-NAV2/Nws-TY/England (H0N3) & $\mathrm{H} 6$ & A/TY/Ontario/63 (H6N8) \\
\hline N4 & A/TY/Ontario/6I I8/67 (H8N4) & $\mathrm{H} 7$ & A/TY/Oregon/7I/(H7N3) \\
\hline N5 & NWS-N5 (H0N5) & $\mathrm{H} 8$ & A/TY/Ontario/6II8/67 (H8N4) \\
\hline N6 & NWS-DK/ENG/56 (H0N6) & $\mathrm{H} 9$ & A/Gull/MD/4435/80 (H9N5) \\
\hline N7 & A/CK/Germany "N"/49 (HION7) & $\mathrm{HIO}$ & A/CK/Germany/"N"/49 (HION7) \\
\hline N8 & Nws-Eq-2 (H0N8) & $\mathrm{HII}$ & A/DK/Memph/546/74 (HIIN9) \\
\hline N9 & A/DK/Memph/546/74 (HIIN9) & $\mathrm{HI} 2$ & A/DK/Alberta/60/76 (HI2N5) \\
\hline $\mathrm{HI}$ & NJ/8/76-EQ (HIN7) & $\mathrm{HI} 3$ & A/Gull/MD/704/77 (HI3N6) \\
\hline $\mathrm{H} 2$ & A/Pintail/Alberta/293/77 (H2N9) & $\mathrm{HI} 4$ & A/Mallard/Gurjev/263/82-A/BEL/42 (HI4NI) \\
\hline $\mathrm{H} 3$ & A/DK/Ukraine/l/63 (H3N8) & $\mathrm{HI5}$ & A/Shearwater/W.Australia/2576/79 (HI5N9) \\
\hline
\end{tabular}

into the S. cerevisiae (strain MYA378; Stratagene, La Jolla, CA) using the Yeast Transformation Kit (Sigma, St Louis, $\mathrm{MO}$ ) following the manufacturer's instructions. Transformed yeast colonies were selected for growth in synthetic complete medium without uracil and expression of the genes was induced with $2 \%$ galactose. Expression of proteins was checked by SDS-PAGE and western blot assays. Briefly, the yeast colonies were grown at $30^{\circ} \mathrm{C}$ for three days collected by centrifugation, and resuspended in $100 \mu \mathrm{l} 1 \times$ loading buffer and boiled for 5 minutes. After centrifugation, the supernatant was analyzed by $12 \%$ SDS-polyacrylamide gels. The gel was transferred to nitrocellulose (NC) membrane by electroblotting. The NC membrane was blocked with 5\% skim milk (SM) and incubated at $37^{\circ} \mathrm{C}$ for 1 hour with AIV polyclonal or monoclonal (polyhistidine or c-Myc) antibody (Sigma, St. Louis, MO). After washing three times with PBST buffer (PBS pH 7.4 with $0.1 \%$ Tween-20), the NC membrane was incubated with alkaline phosphatase-labeled secondary antibody (KPL, Gaithersburg, MD). Detection was obtained using the colorimetric substrate Fast red and Napthol in 0.1 M Tris-HCl buffer pH 8.0.

\section{Isolation of recombinant NP, N3, and N7 proteins from yeast}

The S. cerevisiae culture expressing NP protein was expanded in uracil deficient drop-out media containing $2 \%$ galactose and was grown to an OD600 of 0.8 . Large scale cultures of $20 \mathrm{~L}$ were collected and the pellet was cracked with microfluidizer. The clarified supernatant was used for coating the ELISA plates. For N3 and N7, 2 L of yeast cultures were centrifuged at 3,000 $\times g$, and the pellet ( $\sim 10 \mathrm{gm}$ ) was resuspended in $450 \mathrm{ml}$ of $0.2 \mathrm{~N} \mathrm{NaOH}$ solution, and incubated for $5 \mathrm{~min}$ at room temperature. The suspension was then centrifuged at 2,500 $\times g$ for 5 min and the pellet was treated with $12.5 \mathrm{ml}$ lysis buffer [50 mM Tris-Cl (pH 8.0), $150 \mathrm{mM} \mathrm{NaCl}, 0.02 \%$ sodium azide, $1 \% \mathrm{NP}-40,100 \mu \mathrm{g} / \mathrm{ml}$ PMSF and $1 \mu \mathrm{g} / \mathrm{ml}$ aprotinin] for $30 \mathrm{~min}$ at $4{ }^{\circ} \mathrm{C}$, followed by centrifugation at $9000 \times g$ for $20 \mathrm{~min}$. The supernatant was collected and stored at $-80^{\circ} \mathrm{C}$ until use. The N3 and N7 proteins were purified using c-Myc tagged affinity purification columns (MBL, Japan) and the purified protein was used for coating the ELISA plates.

\section{Enzyme-linked immunosorbent assay (ELISA)}

AIV positive chicken antisera purchased from Charles River Laboratories and negative sera obtained from Synbiotics Inc. was used to optimize the NP-ELISA. The crude NP, purified N3, and N7 proteins were coated onto separate 96-well plates in $\mathrm{PBS}(\mathrm{pH} 8.5)$ overnight at $4^{\circ} \mathrm{C}$. The optimal antigen concentration and the optimal serum dilution were determined by checkerboard titration of each antigen (1:25, 1:50, 1:100, 1:200, 1:400,1:800, $1: 1600)$ and antisera $(1: 25,1: 50,1: 100,1: 200$, $1: 400,1: 800)$. The wells were washed three times with 
0.05\% Tween-20-phosphate-buffered saline (PBST) and subsequently blocked with PBST supplemented with 3\% $(\mathrm{w} / \mathrm{v})$ skimmed milk powder (SMP) for 10 minutes at room temperature (RT). The positive and negative sera were added, followed by incubation for $30 \mathrm{~min}$ at RT. Subsequently, the plates were washed three times with PBST, followed by the addition of goat anti-chicken IgG HRP secondary antibody diluted 1:500 (KPL, Gaithersburg, MD) in PBST with $0.05 \%$ gelatin. After 30 min incubation at RT the plates were washed as described above, and $100 \mu \mathrm{l} /$ well of ABTS substrate (2, 2'-azino-bis (3ethylbenzthiazoline-6-sulfonic acid), (KPL, Gaithersburg, MD) was added. After $15 \mathrm{~min}$ incubation, the reaction was stopped by addition of $100 \mu \mathrm{l} /$ well of $1 \%$ SDS. The optical density at $405 \mathrm{~nm}$ (OD405) was measured with an automated plate spectrophotometer (Thermo Lab Systems, Multiskan, Finland).

\section{The positive threshold and specificity tests}

The ELISA plates were coated with optimal NP/N3/N7 antigen concentration and sera at the optimal dilution were added. The ELISA was performed as described above. The 37 negative sera were used to establish the endpoint cut-off value as the mean OD405 of the 37 negative sera plus 3 standard deviations (mean+3SD). To determine the specificity of NP/N3/N7-ELISA, a panel of sera positive for Newcastle disease, infectious bronchitis and infectious bursal disease was tested.

\section{Optimal Positive/negative ratio and Standard curve}

The standard curve was constructed using the $\mathrm{P} / \mathrm{N}$ ratio method, according to Briggs and Skeeles [23]. Briefly, the OD405 value of the positive serum ( $P$ value) was divided by the OD405 value of the pooled negative sera ( $\mathrm{N}$ value). A regression line was constructed for each serum sample and the dilution at which $\mathrm{P} / \mathrm{N}=1$ was determined. This dilution was called ELISA titre (ET) and was determined for each serum sample. According to Briggs et al. [24], two points were recorded from the regression lines for each serum sample, the $\mathrm{P} / \mathrm{N}$ ratio at 1:100 dilution and the ELISA titre. Using these two points, the ETs were plotted against $\mathrm{P} / \mathrm{N}$ ratios at $1: 100$ and the prediction equation was determined.

\section{Results}

\section{Expression of the recombinant AIV protein}

The expression of the NP, N3 and N7 genes was induced by $2 \%$ galactose and the yeast samples were collected after 72 hours. Subsequently, the yeast lysates were analyzed by Western blot analysis. The NP protein reacted specifically at approximately $64 \mathrm{kD}$ position when probed with polyhistidine MAb (Fig 1a). The N3 and N7 proteins gave specific bands at $32-35 \mathrm{kD}$ position with c-Myc MAb (Fig 1b). The blots were also probed with AIV polyclonal antibody and the proteins reacted at the expected position
(NP at $64 \mathrm{kD}$ and N3/N7 at 32-35 kD position; data not shown). The N3 and N7 proteins were purified using cMyc affinity purification gel. The protein concentration of NP and purified recombinant N3T/N7T was measured and the samples were stored at $-80^{\circ} \mathrm{C}$ until use.

\section{Optimization of ELISA Procedure}

To determine the optimal concentration of the antigen and the test serum, checkerboard titration was performed. The recombinant proteins were immobilized on ELISA plates in two-fold serial dilution ranging from 1:50 to $1: 3200$ and the antisera was also diluted in serial two-fold dilutions ranging from 1:25 to $1: 3200$. The optimal antigen concentration of NP, N3 and N7, as determined by checkerboard titration, was $80 \mu \mathrm{g} / \mathrm{ml}$ (1:400), $60 \mu \mathrm{g} / \mathrm{ml}$ (1:100) and $50 \mu \mathrm{g} / \mathrm{ml}(1: 100)$, respectively (Fig 2a). The optimal serum dilution was obtained by serial titration of high positive serum ( $O D \geq 1$ ) and the pooled negative serum from dilution $1: 25$ to $1: 12800$. The OD405 was plotted against the dilutions and the dilution 1:100 was selected as the dilution for determining the $\mathrm{P} / \mathrm{N}$ ratio as at this dilution the OD of the negative serum was very low, whereas the positive serum had a high OD405 reading. To test the optimal coating buffer, $0.05 \mathrm{M}$ bicarbonate/carbonate buffer ( $\mathrm{pH}$ 9.6), PBS ( $\mathrm{pH} 7.4$ ) or PBS ( $\mathrm{pH} 8.5$ ) was screened. It was found that PBS (pH8.5) was the best coating buffer for immobilization of the proteins.

\section{The ELISA positive threshold}

The end-point cut-off was established by titration as the mean OD405 value of the 37 negative sera plus 3 standard deviations (mean + 3SD). The OD405 values of sera ranged from 0.135 to 0.190 . With NP antigen, the mean OD405 value and SD were 0.163 and 0.031 , respectively. Thus, the positive threshold determined for NP-ELISA was 0.256 . A serum sample was considered positive when its OD405 value at optimal dilution $(1: 100)$ was greater than the positive threshold. Similarly, for N3 and N7-ELISA the end-point cut-off value determined was 0.341 and 0.413 , respectively.

\section{Specificity tests}

The specificity of NP-ELISA was evaluated by testing with panel of sera containing antibodies against AIV, NDV, IBV and IBDV. The results show that the NP-ELISA reacted specifically with all the 24 AIV-positive sera and there was no cross-reaction with antisera against NDV, IBDV and IBV. The specificity of the N3 and N7 antigens was tested using the AIV sera, which are positive for all nine $\mathrm{N}$ subtypes and $15 \mathrm{H}$ subtypes (Table 1 ). The antigens reacted specifically to their respective serum and did not cross-react with any heterologous sera. Both the antigens did not react with the antisera against IBDV, IBV and NDV (Fig. 3a and $3 \mathrm{~b}$ ). This result demonstrates that the antigens have high specificity. 


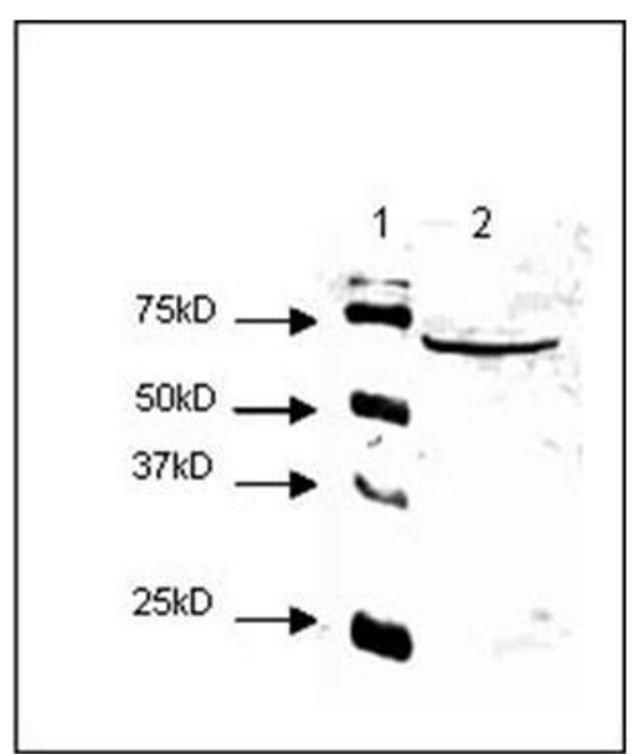

a.

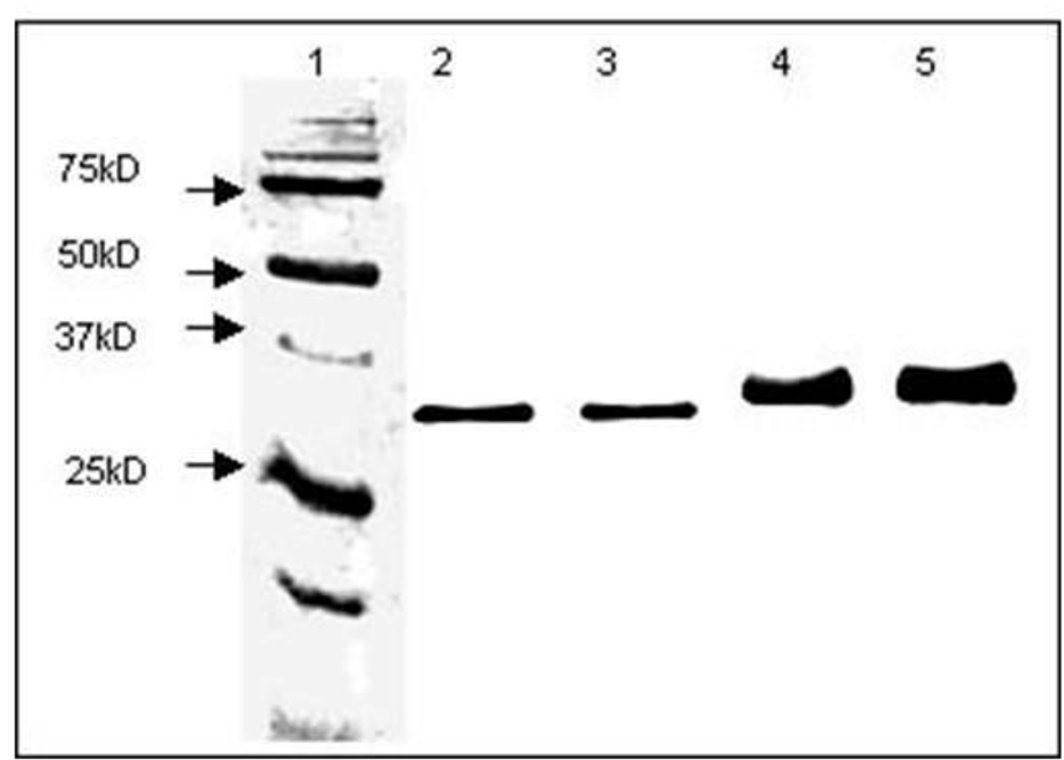

b.

Figure I

Immunoblot analysis of yeast lysate from recombinant yeast clones. The proteins were separated by SDS-PAGE on a $12 \%$ gel, blotted on to nitrocellulose, reacted with respective antibodies, and detected with colorimetric substrate Fast red and napthol alkaline phosphatase (Fig. Ia). Immunoblot of nucleoprotein (NP) probed with polyhistidine monoclonal antibody. Lane I, molecular weight marker and lane 2, recombinant yeast cell lysate expressing (NP) (Fig. Ib). Immunoblot of truncated neuraminidase 3 (N3T) and neuraminidase 7 (N7T) probed with c-Myc monoclonal antibody. Lane I, molecular weight marker; lane 2, recombinant yeast expressing N3T; lane 3, affinity purified N3T; lane 4, recombinant yeast expressing N7T; lane 5, affinity purified N7T. The position of the marker proteins in kD (right) are indicated.

\section{Standard curve}

The regression line of each serum was constructed using the $\mathrm{P} / \mathrm{N}$ ratio (data not shown). The ET of each serum was calculated from this analysis and a standard curve [y (ET) $=1.004 \mathrm{x}(\mathrm{P} / \mathrm{N}$ value at $1: 100$ serum dilution $)+4.0233, \mathrm{R}^{2}$ $=0.9336$ was developed (Fig. 2b). The correlation coefficient ( $r$ value) between ET and $\mathrm{P} / \mathrm{N}$ at 1:100 reached at 0.9336 , indicating that single serum dilution can be used to derive the ELISA titers of antibodies.

\section{Comparisons of NP-ELISA with ProFlok PLUS test}

The NP-ELISA was compared with the commercially available ProFlok PLUS test kit (Synbiotics Inc., CA USA), the results revealed comparable sensitivities, specificities and overall agreements (Table 2). The NP-ELISA showed 98\% agreement and $97 \%$ specificity with the ProFlok PLUS test.

\section{Discussion}

The accurate and prompt diagnosis of AIV infection in birds is a critical component of surveillance and disease control strategy. Currently, virus isolation in embryo- nated eggs or in cell culture followed by subtyping are considered as the standard protocol for detecting avian influenza virus. However, the conventional culture method requires special collection and transport conditions to maintain the viability of the virus and the results may take 1 to 2 weeks, by that time the results may not be relevant. Molecular methods, such as reverse transcription polymerase chain reaction [25-29] real-time RT-PCR [3034], RT-PCR enzyme-linked immunosorbent assay (RTPCR-ELISA) [5,35-37], have also been used for AIV diagnosis. Real-time PCR assays and a DNA microarray analysis for the detection of influenza virus have also been developed [38] but it is useful only as a supplement to PCR-based diagnostic methods. Although, these methods are rapid, sensitive, and specific but the test results often need to be confirmed by additional tests, such as sequence analysis of the PCR-amplified products.

Additionally, a recent report documents the failure of realtime RT-PCR protocol [39], currently used in national avian influenza surveillance programs, to detect subtype $\mathrm{H} 7$ avian influenza viruses isolated from wild birds. The 
A

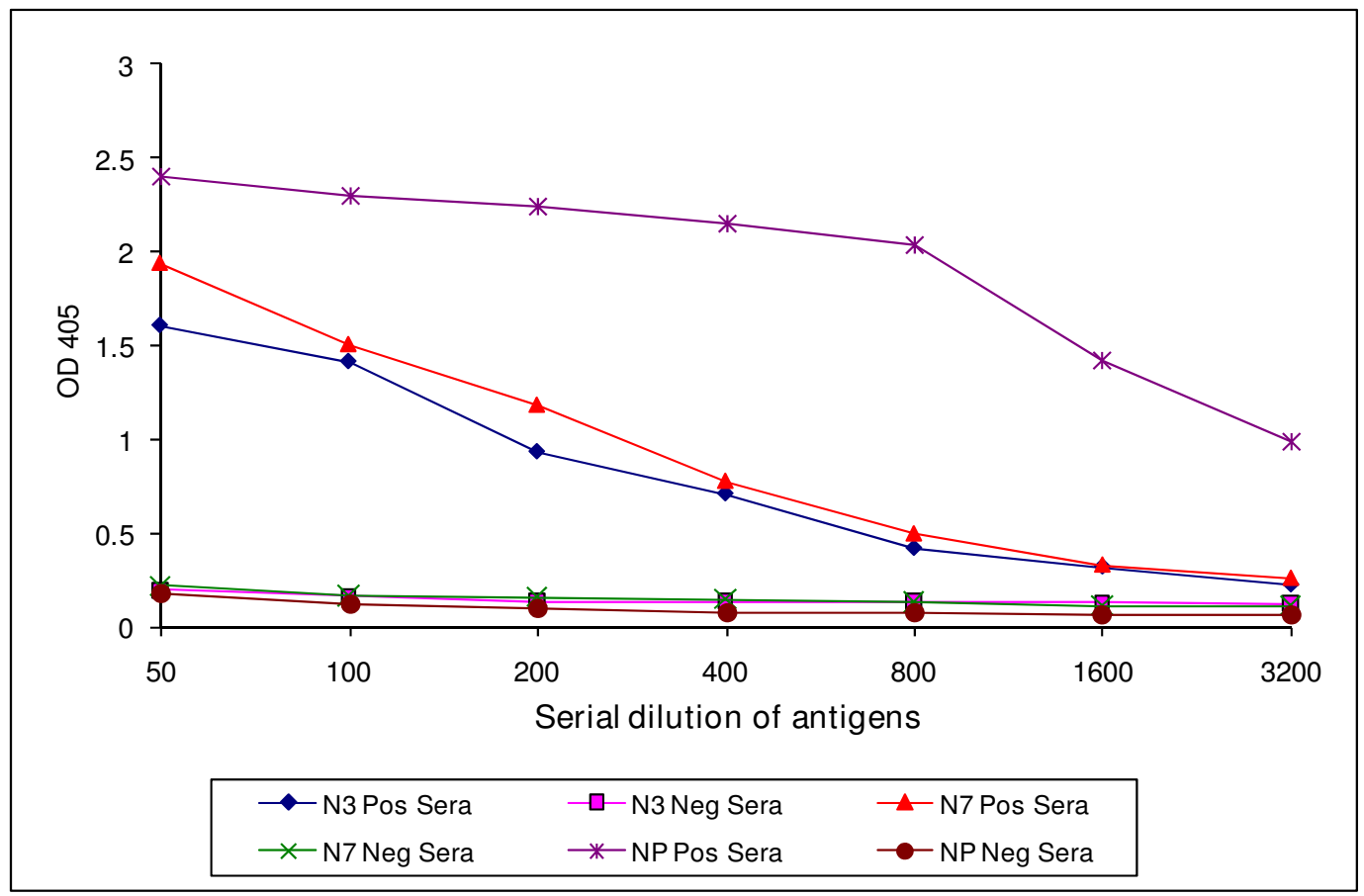

B

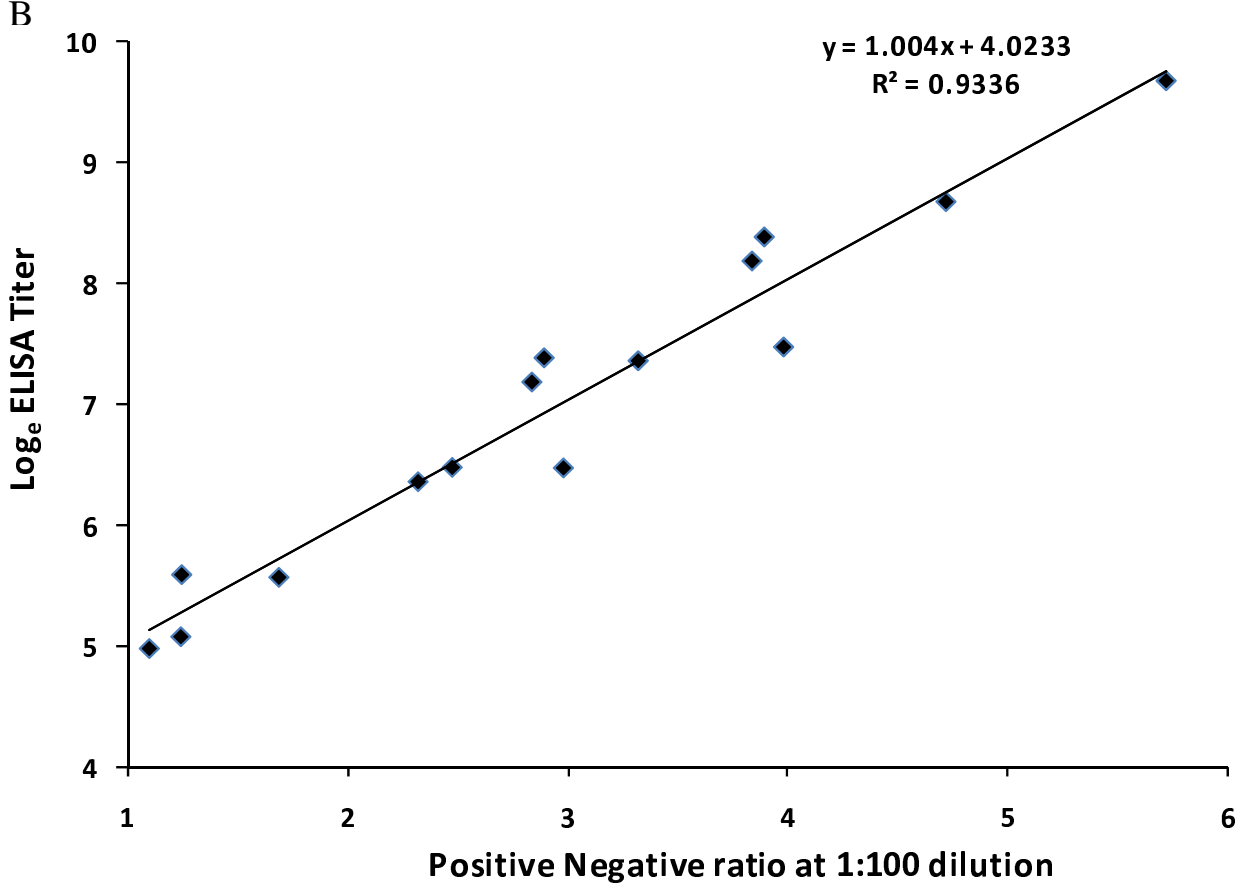

Figure 2

a. Serial dilution of antigens from I:50 to I:3200. All antibodies are at dilution I:100. Selected Ag concentration for NP ( I:400 dilution), N3 and N7 ( I:I 00 dilution) antigen for cross-reactivity study are $80 \mu \mathrm{g} / \mathrm{ml}, 60 \mu \mathrm{g} / \mathrm{ml}$ and $50 \mu \mathrm{g} / \mathrm{ml}$, respectively. $b$. Linear regression of ELISA titre and positive/negative ratio $(P / N)$ ratio of $I: 100$ serum dilution. The regression equation $y=1.004 x+4.0233(r=0.936)$ is shown, where $y$ is the ELISA titre of an individual serum sample, and $x$ is the $\mathrm{P} / \mathrm{N}$ value at $\mathrm{I}: \mathrm{I} 00$ serum dilution. 

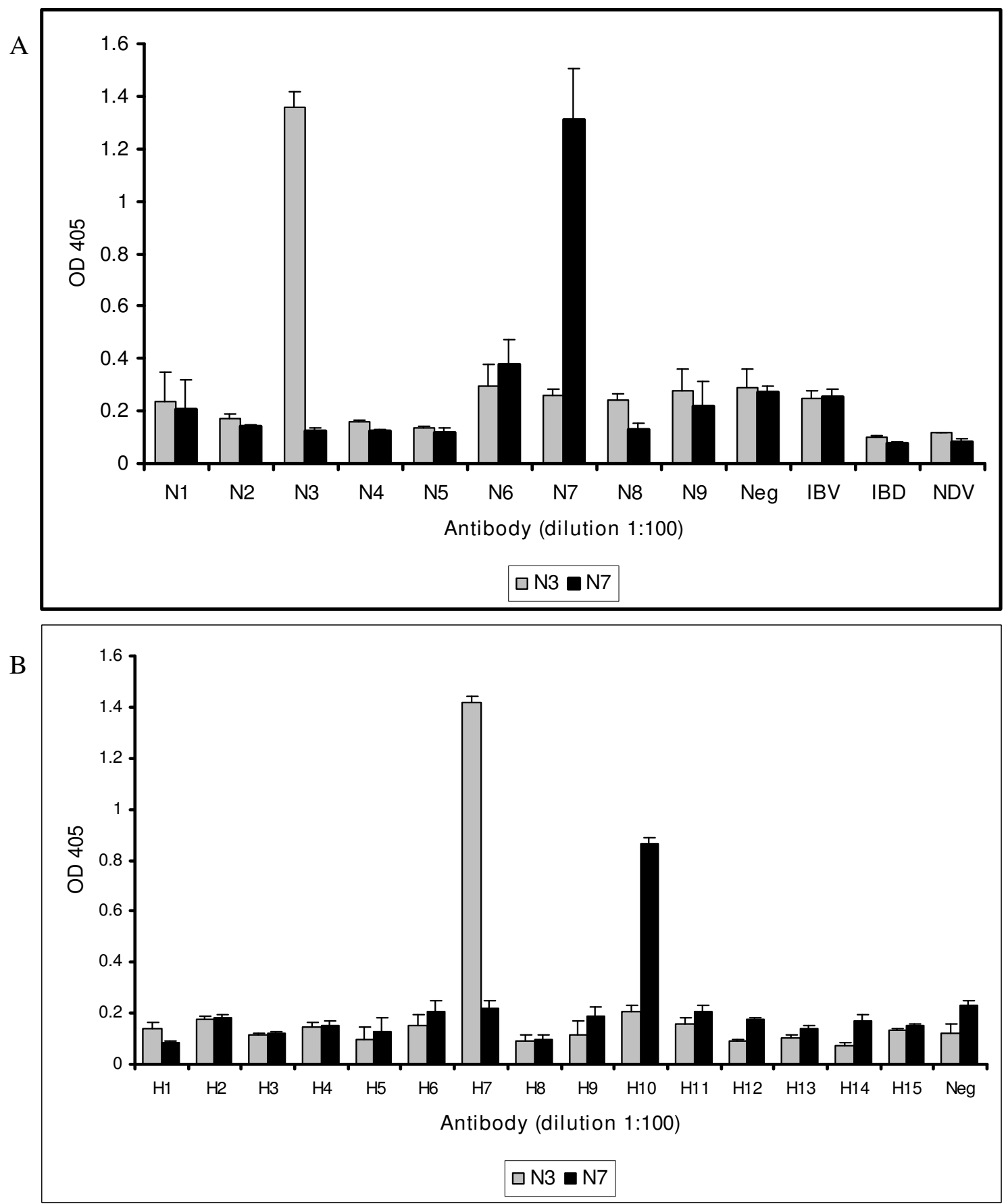

\section{Figure 3}

Reactivity of N3T and N7T antigens with (a) neuraminidase-positive AIV serum and (b) hemagglutinin-positive AIV serum. The ELISA plates were coated with N3T and N7T antigens at $60 \mu \mathrm{g} / \mathrm{ml}$ and $50 \mu \mathrm{g} / \mathrm{ml}$, respectively. The coated plates were reacted with serum samples at single I:I00 dilution and incubated for $30 \mathrm{~min}$ at room temperature, washed three times with PBST (PBS with $0.05 \%$ Tween-20), followed by 30 min incubation with goat anti-chicken IgG HRP-conjugated secondary antibody. The reaction was developed with ABTS (2, 2'-Azinobis [3-thylbenzothiazoline-6-sulfonic acid]-diammonium salt) substrate, stopped after 15 minutes with I\% SDS, and the plates were read in a spectrophotometer using the filter at 405 $\mathrm{nm}$. 
Table 2: Comparative evaluation of NP-ELISA with ProFlok PLUS ELISA kit for detection of anti-AIV antibodies.

\begin{tabular}{ccccc}
\hline Test & $\mathbf{N}^{a}$ & $\%$ agreement $^{b}$ & \% sensitivityc & \% specificityd \\
\hline NP-ELISA & 64 & $98(63 / 64)$ & $100(24 / 24)$ & $97(40 / 41)$
\end{tabular}

${ }^{a}$ Number of antisera tested.

${ }^{b}$ (no. of samples positive by both method + no. of samples negative by both methods)/total no. samples $\times 100$.

c True positive/(true positive + false negative) $\times 100$.

${ }^{d}$ True negative/(true negative + false positive) $\times 100$

findings depict the unreliability of the test for surveillance programs and elucidate the need for new reliable diagnostic testing methods. Antigen capture immunoassay has been another commonly used tool for the diagnosis of AIV [40,41]. The antigen capture tests available are intended for testing AIV infection in humans but are also being used for veterinary purposes. Almost all the tests target the well conserved nucleoprotein and do not provide the information about the circulating neuraminidase subtypes. Surveillance for avian influenza becomes much more difficult because of the inability to differentiate the infected from vaccinated animals (DIVA). The DIVA strategy, although originally proposed in 1986 [42], has only been recently put into practice. Among the different DIVA strategies, one approach is to use an inactivated oil emulsion vaccine containing the same hemagglutinin $(\mathrm{H})$ subtype as the field virus, but a heterologous NA subtype. Serologic surveillance can then be performed for the homologous NA subtype as evidence of natural infection. This novel strategy was first used in Italy in 2000 during an H7N1 outbreak where the turkeys were primarily vaccinated with an H7N3 vaccine. The only field validated DIVA test, based on indirect immunofluorescence assay $[43,44]$, has limitations to be set up as high throughput screening test and the assay requires subjective interpretation of the results. Thus, it is important to develop a serological assay for DIVA, which is sensitive, specific, costeffective, and easy to perform, especially for its application in developing and underdeveloped countries.

In the present study, attempts were made to develop ELISA for detecting antibodies against N3, N7 and NP protein of AI viruses. Neuraminidase proteins are insoluble and very difficult to express. Moreover, they share high percentage similarity which makes it difficult to utilize these proteins in ELISA system. We successfully expressed truncated N3 and N7 proteins in S.cerevisiae in a way to minimize the cross-reaction between the other neuraminidase types. Further, we used these proteins to develop indirect ELISA for detecting antibodies against N3 and N7. The specificity of the N3 and N7 antigens was tested using the AIV sera, positive for all nine $\mathrm{N}$ types and $15 \mathrm{H}$ types. The antigens reacted specifically to their respective serum and did not cross-react with any heterologous sera or exhibited negative reactivity with antisera against IBDV, IBV and NDV. The high specificity of N3 and N7 ELISA demonstrates their suitability to be used for differentiating infected and vaccinated birds.

The other ELISA we developed in this study is based on nucleoprotein (NP), which is highly conserved among AI and can be used as candidate diagnostic antigen because of its group and type specificity. There are previous reports of NP ELISA $[17,18,45,46]$, which use either monoclonal antibodies or the recombinant proteins that are expressed in E.coli and baculovirus. In this study, we exploited the advantages of yeast expression system. The full-length NP protein expressed in S. cerevisiae was used to develop an indirect ELISA assay to detect AIV type-specific antibody. The ELISA developed in this study is cost-effective and can be performed at a single serum dilution, thus reducing the error inherent to serial dilutions. The result of comparative evaluation among NP-ELISA and ProFlok PLUS ELISA showed $98 \%$ agreement and $97 \%$ specificity, proving that the NP-ELISA system developed in this study is as effective as the commercially available one.

In the present study, we utilized the $\mathrm{P} / \mathrm{N}$ ratio regression lines to derive the predication equation from which the NP-ELISA titre (ET) of a serum sample could be determined using one dilution. The co-relation coefficient $(r$ value) between ET and $\mathrm{P} / \mathrm{N}$ at 1:100 reached at 0.9336 , indicating that the ELISA titres of antibodies could be derived at one serum dilution. The NP-ELISA can rapidly evaluate levels of antibodies to AIV and is suitable to detect large numbers of serum samples that would provide scientifically relevant information during a surveillance program to control AIV infections in poultry.

To further strengthen this study, the ELISA system developed based on yeast-expressed antigens was compared with another ELISA system based on baculovirusexpressed antigens (NP, N3, and N7). The recombinant protein expressed in insect cell culture system showed high level of background as compared to the yeast expressed proteins (data not shown), suggesting its unsuitability to be used in indirect ELISA system. A different approach was tried for protein extraction for N3 and $\mathrm{N} 7$ from yeast $(0.2 \mathrm{~N} \mathrm{NaOH})$ and it did not have any negative effect on the quality of the product. This method is simple and relatively inexpensive and bypasses the necessity of the microfluidizer and glass-bead or enzymatic disruption of the yeast cell wall without compromising the quality and quantity of the extracted protein.

\section{Conclusion}

In conclusion, this study demonstrated the expression of the NP, N3, and N7 proteins of AIV in yeast (S. cerevisiae) and their application in developing an indirect ELISA to 
detect NP, N3 and N7 antibodies from AIV-infected chicken sera. With the high degree of conservation and group-specificity of NP, the NP-ELISA developed in this study could detect AI antibodies to all H (1-15) and N (19 ) subtypes. The N3 and N7 ELISAs reacted specifically to their type-specific sera and exhibit no cross-reactivity to other neuraminidase subtypes, indicating high specificity. Furthermore, the tests can be completed within 2 hours and the ELISA system developed in this study could serve as a rapid, accurate and inexpensive diagnostic tool during surveillance and epidemic outbreaks.

\section{Competing interests}

The authors declare that they have no competing interests.

\section{Authors' contributions}

VNV conceived the study. CU planned the experimental design, CU and AA carried out cloning and sequencing. CU drafted the manuscript. All authors critically reviewed and approved the final manuscript.

\section{Acknowledgements}

This project was sponsored by the National Research Initiative of the USDA Cooperative State Research, Education, Extension Service, Grant number 2005-36505-15388. ProFlok ${ }^{\circledR}$ AIV ELISA kit was kindly provided by Chinta Lamichhane of Synbiotics Inc., CA, USA.

\section{References}

I. Palese $P$, Young JF: Variation of influenza A, B, and $\mathbf{C}$ viruses. Science 1982, 21 5: 1468-1474.

2. Webster RG, Bean WJ, Gorman OT, Chambers TM, Kawaoka Y Evolution and ecology of influenza $\mathbf{A}$ viruses. Microbiol Rev 1992, 56:152-179.

3. Rohm C, Zhou N, Suss J, Mackenzie J, Webster RG: Characterization of a novel influenza hemagglutinin, HI5: criteria for determination of influenza A subtypes. Virology 1996 2 I 7:508-516.

4. Fouchier RA, Munster V, Wallensten A, Bestebroer TM, Herfst S, Smith D, Rimmelzwaan GF, Olsen B, Osterhaus AD: Characterization of a novel influenza $A$ virus hemagglutinin subtype (HI6) obtained from black-headed gulls. I Virol 2005, 79:28|4-2822

5. Munch M, Nielsen LP, Handberg KJ, Jorgensen PH: Detection and subtyping ( $\mathrm{H5}$ and $\mathrm{H7}$ ) of avian type $A$ influenza virus by reverse transcription-PCR and PCR-ELISA. Arch Virol 200I, 146:87-97.

6. Suarez DL, Schultz-Cherry S: Immunology of avian influenza virus: a review. Dev Comp Immunol 2000, 24:269-283.

7. Vabret A, Sapin G, Lezin B, Mosnier A, Cohen J, Burnouf L, Petitjean J, Gouarin S, Campet M, Freymuth F: Comparison of three nonnested RT-PCR for the detection of influenza A viruses. J Clin Virol 2000, 17:167-175.

8. Alexander DJ, Lister SA, Johnson MJ, Randall CJ, Thomas PJ: An outbreak of highly pathogenic avian influenza in turkeys in Great Britain in 1991. Vet Rec 1993, 132:535-536.

9. Buisch WW, Hall AE, McDaniel HA: I983-I984 lethal avian influenza outbreak. Proceedings of the 88th Annual Meeting of the US Animal Health Association US Animal Health Association, Richmond, VA 1984:430-445

10. Normile D: Infectious diseases. Stopping Asia's avian flu: a worrisome third outbreak. Science 2004, 303:447.

II. WHO: H5N I avian influenza: timeline of major events. 2009 [http://www.who.int/csr/disease/avian influenza/ai timeline/en/ index.html].

12. Fielding R, Bich TH, Quang LN, Lam WW, Leung GM, Tien TQ, Ho EY, Anh LV: Live poultry exposures, Hong Kong and Hanoi, 2006. Emerg Infect Dis 2007, I 3:1065-1067.
13. FAO: Guiding principles for highly pathogenic avian influenza surveillance and diagnostic networks in Asia. FAO expert meeting on surveillance and diagnosis of avian influenza in Asia, Bangkok 2004:2I-23.

14. Snyder DB, Marquardt WW, Yancey FS, Savage PK: An enzymelinked immunosorbent assay for the detection of antibody against avian influenza virus. Avian Dis |985, 29:|36-|44.

I5. Boivin G, Hardy I, Kress A: Evaluation of a rapid optical immunoassay for influenza viruses (FLU OIA test) in comparison with cell culture and reverse transcription-PCR. J Clin Microbiol 200I, 39:730-732.

16. Kaiser L, Briones MS, Hayden FG: Performance of virus isolation and Directigen Flu $A$ to detect influenza $A$ virus in experimental human infection. J Clin Virol 1999, 14:191-197.

17. Wu R, Hu S, Xiao Y, Li Z, Shi D, Bi D: Development of indirect enzyme-linked immunosorbent assay with nucleoprotein as antigen for detection and quantification of antibodies against avian influenza virus. Vet Res Commun 2007, 3 I:63I-64I.

18. Starick E, Werner O, Schirrmeier H, Kollner B, Riebe R, Mundt E: Establishment of a competitive ELISA (cELISA) system for the detection of influenza $A$ virus nucleoprotein antibodies and its application to field sera from different species. J Vet Med B Infect Dis Vet Public Health 2006, 53:370-375.

19. Harley VR, Hudson PJ, Coupar BE, Selleck PW, Westbury H, Boyle $D B$ : Vaccinia virus expression and sequence of an avian influenza nucleoprotein gene: potential use in diagnosis. Arch Virol 1990, I I 3:133-141.

20. Mather KA, White JF, Hudson PJ, McKimm-Breschkin JL: Expression of influenza neuraminidase in baculovirus-infected cells. Virus Res 1992, 26:127-139.

21. Tanimotoa T, Nishimurab $Y$, Matsuurab $Y$, Fukec I, Ishikawac T, Yamanishid K, Tamura S: Expression of influenza neuraminidase in CHO-KI cells. International Congress Series 2004, I 263:568-572.

22. Romanos MA, Scorer CA, Clare J]: Foreign gene expression in yeast: a review. Yeast 1992, 8:423-488.

23. Briggs DJ, Skeeles JK: An enzyme-linked immunosorbent assay for detecting antibodies to Pasteurella multocida in chickens. Avian Dis 1984, 28:208-2I5.

24. Briggs DJ, Whitfill CE, Skeeles JK, Story JD, Reed KD: Application of the positive/negative ratio method of analysis to quantitate antibody responses to infectious bursal disease virus using a commercially available ELISA. Avian Dis 1986, 30:216-218.

25. Phipps LP, Essen SC, Brown IH: Genetic subtyping of influenza A viruses using RT-PCR with a single set of primers based on conserved sequences within the HA2 coding region. J Virol Methods 2004, I22: I 19-I22.

26. Pang Y, Wang H, Girshick T, Xie Z, Khan MI: Development and application of a multiplex polymerase chain reaction for avian respiratory agents. Avian Dis 2002, 46:691-699.

27. Xie Z, Pang YS, Liu J, Deng X, Tang X, Sun J, Khan MI: A multiplex RT-PCR for detection of type $A$ influenza virus and differentiation of avian $\mathrm{H5}, \mathrm{H7}$, and $\mathrm{H} 9$ hemagglutinin subtypes. $\mathrm{Mol}$ Cell Probes 2006, 20:245-249.

28. Lee MS, Chang PC, Shien JH, Cheng MC, Shieh HK: Identification and subtyping of avian influenza viruses by reverse transcription-PCR. J Virol Methods 200I, 97:|3-22.

29. Starick E, Romer-Oberdorfer A, Werner O: Type- and subtypespecific RT-PCR assays for avian influenza A viruses (AIV). Vet Med B Infect Dis Vet Public Health 2000, 47:295-30I.

30. Spackman E, Senne DA, Bulaga LL, Myers T], Perdue ML, Garber LP Lohman K, Daum LT, Suarez DL: Development of real-time RTPCR for the detection of avian influenza virus. Avian Dis 2003, 47: $1079-1082$.

31. Chen W, He B, Li C, Zhang X, Wu W, Yin X, Fan B, Fan X, Wang J: Real-time RT-PCR for H5NI avian influenza $A$ virus detection. I Med Microbiol 2007, 56:603-607.

32. Das A, Spackman E, Senne D, Pedersen J, Suarez DL: Development of an internal positive control for rapid diagnosis of avian influenza virus infections by real-time reverse transcriptionPCR with lyophilized reagents. J Clin Microbiol 2006, 44:3065-3073.

33. Abolnik $C$ : $\mathbf{A}$ rapid and sensitive real-time reverse transcription PCR for the pathotyping of South African H5N2 avian influenza viruses. Onderstepoort / Vet Res 2008, 75:347-35 I. 
34. Spackman E, Suarez DL: Type A influenza virus detection and quantitation by real-time RT-PCR. Methods Mol Biol 2008, 436: $19-26$.

35. Dybkaer K, Munch M, Handberg KJ, Jorgensen PH: RT-PCR-ELISA as a tool for diagnosis of low-pathogenicity avian influenza. Avian Dis 2003, 47: 1075-1078.

36. Dybkaer K, Munch M, Handberg KJ, Jorgensen PH: Application and evaluation of RT-PCR-ELISA for the nucleoprotein and RTPCR for detection of low-pathogenic $\mathrm{H} 5$ and $\mathrm{H7}$ subtypes of avian influenza virus. I Vet Diagn Invest 2004, 16:5I-56.

37. Chaharaein B, Omar AR, Aini I, Yusoff K, Hassan SS: Reverse transcriptase-polymerase chain reaction-enzyme linked immunosorbent assay for rapid detection of avian influenza virus subtype H9N2. Arch Virol 2006, I 5 I:2447-2459.

38. $\mathrm{Li}$ J, Chen $\mathrm{S}$, Evans $\mathrm{DH}$ : Typing and subtyping influenza virus using DNA microarrays and multiplex reverse transcriptase PCR. J Clin Microbiol 200I, 39:696-704.

39. Xing Z, Cardona C, Dao P, Crossley B, Hietala S, Boyce W: Inability of real-time reverse transcriptase PCR assay to detect subtype $\mathbf{H 7}$ avian influenza viruses isolated from wild birds. J Clin Microbiol 2008, 46: I844-1846.

40. Slemons RD: Rapid antigen detection as an aid in early diagnosis and control of avian influenza. In Fourth International Symposium on Avian Influenza D E Swayne United States Animal Health Association, Athens, GA; 1998:313-317.

41. Ryan-Poirier KA, Katz JM, Webster RG, Kawaoka Y: Application of Directigen FLU-A for the detection of influenza A virus in human and nonhuman specimens. J Clin Microbiol 1992, 30:1072-1075.

42. Beard CW: To vaccinate or not to vaccinate. In Proceedings of the second international symposium on avian influenza Richmond Edited by: Beard CW, Easterday BC. Virginia: United States Animal Health Association; 1986:258-263.

43. Capua I, Terregino C, Cattoli G, Mutinelli F, Rodriguez JF: Development of a DIVA (Differentiating Infected from Vaccinated Animals) strategy using a vaccine containing a heterologous neuraminidase for the control of avian influenza. Avian Pathol 2003, 32:47-55.

44. Cattoli G, Terregino C, Brasola V, Rodriguez JF, Capua I: Development and preliminary validation of an ad hoc NI-N3 discriminatory test for the control of avian influenza in Italy. Avian Dis 2003, 47: $1060-1062$

45. Jin M, Wang G, Zhang R, Zhao S, Li H, Tan Y, Chen H: Development of enzyme-linked immunosorbent assay with nucleoprotein as antigen for detection of antibodies to avian influenza virus. Avian Dis 2004, 48:870-878.

46. Yang M, Berhane Y, Salo T, Li M, Hole K, Clavijo A: Development and application of monoclonal antibodies against avian influenza virus nucleoprotein. J Virol Methods 2008, 147:265-274.

Publish with Bio Med Central and every scientist can read your work free of charge

"BioMed Central will be the most significant development for disseminating the results of biomedical research in our lifetime. "

Sir Paul Nurse, Cancer Research UK

Your research papers will be:

- available free of charge to the entire biomedical community

- peer reviewed and published immediately upon acceptance

- cited in PubMed and archived on PubMed Central

- yours - you keep the copyright 